\section{BONE TISSUE BEHAVIOR OF RATS WITH EXPERIMENTAL PERIODONTITIS SUBJECTED TO PHYSICAL EXERCISE}

\author{
COMPORTAMENTO DO TECIDO ÓSSEO DE RATOS COM PERIODONTITE SUBMETIDOS AO EXERCÍCIO FÍSICO
}

COMPORTAMIENTO DEL TEJIDO ÓSEO DE RATAS CON PERIODONTITE SOMETIDAS AL EJERCICIO FÍSICO

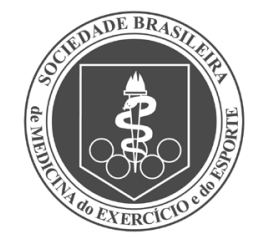

Original Article Artigo Original Artículo Original
Bruna Martinazzo Bortolini' (Dental surgeon)

Pedro Henrique de Carli Rodrigues (Dental surgeon)

Lidiane Ura Afonso Brandão (Physiotherapist)

Danielle Shima Luize ${ }^{1}$ (Dental Surgeon)

Gladson Ricardo Flor Bertolini' (Physiotherapist)

Carlos Augusto Nassar (Dental Surgeon)

Patricia Oehlmeyer Nassar ${ }^{1}$ (Dental Surgeon)

1. Universidade Estadual do Oeste do Paraná (UNIOESTE), Cascavel, PR, Brazil.

\section{Correspondence}

Patricia Oehlmeyer Nassar. Rua Pernambuco, 593, apto 504, Centro, Cascavel, PR, Brazil. 85810-020. ponassar@yahoo.com

\begin{abstract}
Introduction: It is possible that physical activity protects the periodontium by mitigating excessive inflammatory response of the individual. There is some evidence from longitudinal studies and a prospective study demonstrating that physically active adults have experienced a decrease in the risk of periodontitis. To date no study has jointly explored the relationship of physical activity and periodontitis using inflammatory biomarkers. Objective: In this regard, the objective was to assess the bone tissue behavior of rats with experimental periodontitis subjected to aquatic exercise. Methods: Twenty-four male Wistar rats were divided into four groups: 1) without periodontitis and without exercise (CS); 2) without periodontitis and with exercise (CE); 3) with periodontitis and without exercise (DPS); 4) with periodontitis and with exercise (DPE). The animals from groups CE and DPE had swimming sessions for four weeks and the DPS and DPE groups were subjected to ligature-induced periodontitis. After 30 days the animals were sacrificed, and had their right and left hemimandibles removed for radiographic and histological analysis. The data obtained were analyzed and evaluated through ANOVA and Tukey tests. Results: Bone loss in the animals from the DPE group was found to be significantly lower $(61.7 \pm 2.2 ; p<0.05)$ than in those from the DPS group $(84.5 \pm 1.2 ; p<0.05)$, while in terms of the number of osteoblasts (DPS=11.0 \pm 1.4 ; $\mathrm{DPE}=10.7 \pm 5.2$ ) and osteocytes (DPS=17.3 \pm 3.1 ; $D P E=19.0 \pm 4.4)$, there was no significant decrease $(p<0.05)$ in the groups subjected to experimental periodontitis, regardless of physical exercise. Conclusion: Physical exercise was found to have a protective effect in relation to bone height and did not influence bone density. Level of evidence II; Therapeutic studies investigation of treatment results.
\end{abstract}

Keywords: Exercise; Periodontal diseases; Bones.

\section{RESUMO}

Introdução: Épossível que a a tividade física proteja o periodonto por atenuar a resposta inflamatória excessiva do indivíduo. Há algumas evidências em estudos longitudinais e um estudo prospectivo que demonstram que adultos fisicamente ativos têm tido diminuição do risco de periodontite. Até o momento, nenhum estudo explorou conjuntamente o relacionamento da atividade física com a periodontite, utilizando biomarcadores inflamatórios. Objetivo: Neste sentido, objetiva-se avaliar o comportamento do tecido ósseo de ratos com periodontite experimental submetidos ao exercício físico em meio aquático. Métodos: Foram utilizados 24 ratos Wistar machos, divididos em quatro grupos: 1) Grupo sem periodontite esem exercício (CS); 2) Grupo sem periodontite e com exercício (CE); 3) Grupo com periodontite e sem exercício (DPS); 4) Grupo com periodontite e com exercício (DPE). Os animais dos grupos CE e DPE realizaram natação por quatro semanas e nos animais dos grupos DPS e DPE induziu-se a doença periodontal por ligadura. Aos 30 dias, os animais foram sacrificados, sendo retiradas as hemimandíbulas do lado direito e esquerdo para análise radiográfica e histológica. Os dados obtidos foram analisados e avaliados através dos testes ANOVA e Tukey. Resultados: Foi possivel observar que nos animais do grupo DPE, a perda óssea foi significantemente menor $(61,7 \pm 2,2 ; p<0,05)$ do que no grupo DPS $(84,5 \pm 1,2 ; p<0,05)$. Na quantidade de osteoblastos (DPS $=11,0 \pm 1,4 ;$ $D P E=10,7 \pm 5,2)$ e de osteócitos (DPS $=17,3 \pm 3,1 ; D P E=19,0 \pm 4,4)$, não houve diminuição significativa $(p<0,05)$ nos grupos submetidos à periodontite experimental, independentemente do exercício físico. Conclusão: Foi possivel observar que o exercício físico apresentou um efeito protetor com relação à altura óssea e não influenciou a densidade do osso. Nível de evidência: Il; Estudos terapêuticos-investigação dos resultados do tratamento.

Descritores: Exercício físico; Doenças periodontais; Ossos.

\section{RESUMEN}

Introducción: Es posible que la actividad física proteja el periodonto por atenuar la respuesta inflamatoria excesiva del individuo. Hay algunas evidencias en estudios longitudinales y un estudio prospectivo que demuestran que los adultos físicamente activos tuvieron riesgo reducido de periodontitis. Hasta el momento, ningún estudio exploró conjuntamente la relación de la actividad física con la periodontitis utilizando biomarcadores inflamatorios. Objetivo: En este sentido, se pretende evaluar el comportamiento del tejido óseo de ratas con periodontitis experimental sometidos al ejercicio físico en en medio acuático. Métodos: Se utilizaron 24 ratas Wistar machos, divididas en cuatro grupos: 1) Grupo sin periodontitis y sin ejercicio (CS); 2) Grupo sin periodontitis y con ejercicio (CE); 3) Grupo con periodontitis 
y sin ejercicio (DPS); 4) Grupo con periodontitis y con ejercicio (DPE). Los animales de los grupos CE y DPE realizaron natación por cuatro semanas y en los animales de los grupos DPS y DPE se indujo la enfermedad periodontal por ligadura. A los 30 días, se sacrificaron los animales, siendo retiradas las hemimandibulas del lado derecho e izquierdo para análisis radiográfico e histológico. Los datos obtenidos fueron analizados y evaluados por las pruebas ANOVAy Tukey. Resultados: Se observó que en los animales del grupo DPE, la pérdida ósea fue significativamente menor (61,7 $\pm 2,2 ; p<0,05)$ que en el grupo DPS $(84,5 \pm 1,2 ; p<0,05)$. En la cantidad de osteoblastos (DPS $=11,0 \pm 1,4 ;$ DPE $=$ $10,7 \pm 5,2)$ y de osteocitos (DPS $=17,3 \pm 3,1 ; D P E=19,0 \pm 4,4)$, no hubo una disminución significativa $(p<0,05)$ en los grupos sometidos a la periodontitis experimental, independientemente de ejercicio físico. Conclusión: Fue posible observar que el ejercicio presentó un efecto protector con relación a la altura ósea, no influenció en la densidad del hueso. Nivel de evidencia: Il; Estudios terapéuticos-investigación de los resultados del tratamiento

Descriptores: Ejercicio; Enfermedades periodontales; Huesos.

\section{INTRODUCTION}

Regular physical exercises lead to important physiological and morphological adaptations to maintain the body's homeostasis, and these adaptations are important in the control of multiple diseases, particularly cardiovascular and endocrine-metabolic diseases. Many studies have found that physical exercises are capable of promoting changes to a number of functions of the human body and the body of rats ${ }^{1}$. Besides, they are also capable of speeding up repair processes in inflammation². In this sense, some studies have shown that the exercises interfere with several stages of the inflammatory process, promoting the migration of leukocytes towards the focus of inflammation (chemotaxis) and increased phagocytosis capacity of these cells in humans and animals, besides increasing the antitumor activity of macrophages ${ }^{3}$.

Inflammation is an adaptive response that is triggered by stimuli and harmful conditions, such as infection and tissue injury. Considerable progress has been achieved in understanding the cellular and molecular events involved in the acute inflammatory response to infection and, to a lesser extent, tissue aggression. Also, the events that lead to localized chronic inflammation, especially chronic infections and autoimmune diseases, are partially understood. However, little is known about the causes and mechanisms of chronic systemic inflammation, which occurs in a wide variety of diseases, including type 2 diabetes and cardiovascular diseases. These chronic inflammatory states do not seem to be related to the classical causes of inflammation: infection and aggression. Instead, they appear to be associated with tissue malfunction: homeostatic imbalance of one of many physiological systems that has no direct functional relationship to host defense or tissue repair ${ }^{4}$.

Inflammatory response to an infection, when it is intended to restore homeostasis, may become harmful if it is excessive or unregulated. Under these conditions, inflammation plays an essential role in the pathogenesis of many chronic diseases, including periodontitis ${ }^{4}$.

Periodontitis is a chronic inflammatory disease initiated by a pathogenic microorganism organized into a biofilm that results in the selective destruction of the periodontal tissues, which may lead to tooth loss. However, tissue destruction in periodontitis does not follow a linear pattern. In fact, periodontitis is characterized by alternating phases of exacerbation and remission of the disease, as well as periods of inactivity. In this context, the cytokines that may target the cellular response during these overlapping stages of inflammation and tissue healing may interact at different levels. However, little is known about the interaction between cytokines and growth factors that modulate inflammation and tissue repair ${ }^{5}$.

Sanders et al. (2009) 6 found that among the individuals that engaged in physical activity nearly every day for 30 minutes or more, those who had moderate to advanced periodontitis presented greater reduction of the inflammatory biomarker C-reactive protein (CRP) in the gingival fluid than controls without periodontitis, hence suggesting a protective effect of physical activity on this marker.

Physical activity may protect the periodontium because it attenuates an excessive inflammatory response from the host ${ }^{6}$. Physically active individuals are less likely to develop PD compared to physically inactive individuals ${ }^{7}$. However, the effects of physical exercise on parameters of inflammation and alveolar bone loss in individuals with PD have been poorly investigated ${ }^{8}$. The increase of proinflammatory mediators in patients with PD contributes to the increase of alveolar bone loss. Studies have investigated strategies to prevent the progression of alveolar bone loss, including new approaches to improve the immune response of the host and the strategies known to promote immunomodulation include physical exercise. Long-term physical activity may make the body less susceptible to inflammation and infections, thus becoming a promising factor against the progression of $\mathrm{PD}^{8}$. The purpose of this study is to evaluate the behavior of the mandibular bone tissue of rats undergoing physical exercise with or without periodontal disease.

\section{METHODS}

The study included 24 Wistar rats from UNIOESTE's central vivarium, weighing $100 \mathrm{~g}$ on average. The animals were kept under controlled conditions of temperature $\left(23 \pm 2^{\circ} \mathrm{C}\right.$ ) and light (cycle of 12 hours of light and 12 hours of darkness -7 a.m. -7 p.m.) and received water and offthe-shelf feed ad libitum. All experimental protocols were approved by UNIOESTE's Committee on Animal Experimentation and Practical Classes (CEEAAP) under Project Number 32/14 and Certificate Number 23/16.

\section{Experimental Groups}

The animals were randomly divided into four groups of six animals each, based on a similar study by Brandão et al. (2017) ${ }^{9}$ :

1. Group (CS): control and no exercise.

2. Group (EC): control and exercise.

3. Group (DPS): with periodontal disease and no exercise.

4. Group (DPE): with periodontal disease and exercise.

\section{Induction of periodontal disease}

The animals were anesthetized (xylazine $0.04 \mathrm{~mL} / 100 \mathrm{~g}$ and ketamine $0.08 \mathrm{~mL} / 100 \mathrm{~g}$ ) and placed on an appropriate operating table, which allowed to keep the rats with their mouths open, thus making it easy to access the teeth of the posterior region of the mandible. With modified forceps and an exploratory probe, a cotton thread no. 40 was placed around the first lower right molar tooth. This ligature served as a gingival irritant for 30 days, causing the accumulation of bacterial plaque and consequent development of periodontal disease ${ }^{10}$. 


\section{Aerobic Exercise Protocol}

Prior to the protocol of induction of periodontal disease, the animals from groups CE and DPE underwent a 15-minute swimming pool familiarization training that began one week before, for three times a week.

Two days after induction of periodontal disease, the groups performed aerobic swimming exercise for four weeks, with progressive increase of time, including 15 minutes in the first week, 30 minutes in the second week, and so on, until it reached 60 minutes on the fourth week, on a daily basis, with a two-day interval between each week. The site used was an oval tank with 200L capacity, $60 \mathrm{~cm}$ depth and temperature controlled at $32^{\circ} \pm 1^{\circ} \mathrm{C}^{11}$.

\section{Radiographic Analysis}

At the end of the treatment period, all animals were weighed and anesthetized with ketamine $(50 \mathrm{mg} / \mathrm{kg})$ and xylazine $(10 \mathrm{mg} / \mathrm{kg})$, and decapitated on guillotine. The right hemi-jaws were taken. They were radiographed using a Dabi-Atlante Spectro X-ray device with $70 \mathrm{Kvp}$ and $8 \mathrm{~mA}$, maintaining a focus/film distance of $50 \mathrm{~cm}$ and exposure time of 0.3 seconds

The radiographic images were analyzed by the Sigma-Scan 2.0 program. Linear measurement was taken from the rat's cementoenamel junction to the alveolar bone crest on the mesial side of the first lower molar tooth. Measurements were taken and repeated three times and the between them average was taken. Subsequently, the measurements were transformed into millimeters using a scale made of radiopaque material (lead), which was precisely measured using a pachymeter and X-rayed with the same standardizations as those of the experiment. ${ }^{12}$

\section{Histological Analysis of the Jaws}

The right hemi-jaws were fixed in 10\% formalin solution for 24 hours, then washed in distilled water and decalcified in $5 \%$ trichloroacetic acid (TCA) for about 10 days. The samples were dehydrated for an hour in $70 \%, 80 \%$ and $90 \%$ and $95 \%$ alcohols overnight, and in $100 \%$ alcohol for four 1 -hour baths. Then, the material was diaphanized, impregnated and embedded in paraffin, cut out into $7 \mu \mathrm{m}$ thickness in Olympus CUT 4055 microtomes, then stained in hematoxylin and eosin ${ }^{13}$.

Microscopic analysis was performed by a single examiner through the evaluation of stained histological sections. The slides were analyzed using a commonly transmitted light microscope (Leica Microsystems, Switzerland) to count the osteocytes and osteoblasts of the hemi-jaws of the animals.

\section{Data Analysis}

The data were analyzed and evaluated by the ANOVA and Tukey tests. The level of significance was set at $p<0.05$ and the results were expressed as mean \pm standard deviation of the mean.

\section{RESULTS}

Table 1 shows the mean measurement of the distance from the cementoenamel junction to the alveolar bone crest. It was found that only in the groups with induced periodontitis (DPS and DPE) it was significantly increased, and in the group that swam performed physical swimming effort (DPE) the bone loss was significantly smaller than in the group with periodontal disease (DPS).

Table 2 shows the mean number of osteoblast and osteocyte cells of the animals'jaw. It was found that both in the number of osteoblasts and osteocytes, there was a significant decrease in the groups undergoing experimental periodontitis, regardless of the physical exercise.
Table 1. Mean values of the distance from the cementoenamel junction to the alveolar bone crest of the rats of the established groups. The values represent mean \pm standard deviation and are expressed in pixels.

\begin{tabular}{c|c}
\hline Groups & Means \\
\hline Group (CS): control and no exercise. & $47.6 \pm 1.1 \mathrm{~A}$ \\
\hline Group (EC): control and exercise. & $47.6 \pm 1.1 \mathrm{~A}$ \\
\hline Group (DPS): with periodontal disease and no exercise. & $84.3 \pm 1.1 \mathrm{C}$ \\
\hline Group (DPE): with periodontal disease and exercise. & $61.5 \pm 2.1 \mathrm{~B}$ \\
\hline
\end{tabular}

Different letters, $(p<0.05)$ statistically different data within the same group.

Table 2. Mean values of the number of osteoblasts and osteocytes of the rats of the established groups. The values represent mean \pm standard deviation and are expressed as a percentage.

\begin{tabular}{c|c|c}
\hline Groups & Osteoblasts & Osteocytes \\
\hline Group (CS): control and no exercise. & $19.2 \pm 4.8 \mathrm{~A}$ & $33.9 \pm 9.6 \mathrm{~A}$ \\
\hline Group (CT): control and exercise. & $19.4 \pm 3.4 \mathrm{~A}$ & $29.3 \pm 6.0 \mathrm{~A}$ \\
\hline Group (DPS): with periodontal disease and no exercise. & $11.0 \pm 1.4 \mathrm{~B}$ & $17.3 \pm 3.1 \mathrm{~B}$ \\
\hline Group (DPE): with periodontal disease and exercise. & $10.7 \pm 5.2 \mathrm{~B}$ & $19.0 \pm 4.4 \mathrm{~B}$ \\
\hline Different letters, $(\mathrm{p}<0.05)$ statistically different data within the same group.
\end{tabular}

\section{DISCUSSION}

Recently, it has been shown that healthy diet and moderate regular physical exercise have antioxidant and anti-inflammatory effects, thereby reducing the risk of chronic diseases or contributing to their treatment ${ }^{7}$. Observational studies show consistency in the inverse association between systemic inflammation and physical activity markers and data from multiple interventional studies confirm the anti-inflammatory effect of exercise $e^{7,14}$.

In our study, it was found that bone loss evaluated from the cementoenamel junction up to the alveolar bone crest was significantly increased only in the groups with induced periodontitis (DPS and DPE), and in the group that performed physical swimming effort (DPE), bone loss was significantly smaller than in the periodontal disease group (DPS) (table 1), thus showing, in this case, that physical exercise served as a protective effect when associated with periodontal disease. When the osteoblast and osteocyte counts were evaluated, a significant decrease was found in the groups undergoing experimental periodontitis, but without any change when associated with physical exercise. Andrade et al. (2017) $)^{8}$, evaluating animals trained with 1 hour/day swimming sessions for 8 weeks, also found that physical training attenuated alveolar bone loss and levels of loss of epithelial insertion of rats with PD. The distance from the cementoenamel junction to the alveolar bone crest assessed histologically was found to be lower in the group with PD and trained than in the untrained PD group, corroborating with our study regarding the protective effect of physical exercise against the progression of PD.

Also according to Andrade et al. (2017) ${ }^{8}$, attenuation of alveolar bone loss and loss of epithelial insertion in trained animals may be related to improved inflammatory profile, as there was an increase in the IL-10 expression (Interleukin-10) and a decrease in TNF-a (tumor necrosis factor-a) in the adjacent tissues of these animals. Besides, the decrease in the TNF-a/L-10 ratio observed in animals with induced periodontitis undergoing training confirms the improvement in the inflammatory state, as the increase in this ratio is indicative of more severe periodontitis. IL-10 plays a strong anti-inflammatory role and its increase is related to bone preservation, mainly by the inhibition of osteoclastogenesis. In a similar study conducted by our research group, Brandão et al. (2017) found different results, where the expression of TNF-a in the gingival tissue of rats undergoing physical swimming exercise with induced periodontitis was not different in the DP groups with exercise and without exercise. However, in this study, the training protocol was performed for 4 weeks, starting with 15 minutes per day for 5 days and increasing 
15 minutes per day each week, reaching 60 minutes per day in the last week. Nevertheless, the results showed an improvement in the behavior of muscle tissue with a process of acceleration and muscle regeneration.

Studies in humans also suggest a protective effect of physical activity when associated with periodontitis. Sanders et al. (2009) ${ }^{6}$ found that, among individuals who practiced physical activity nearly every day for 30 minutes or more, those who had moderate to advanced periodontitis presented a greater reduction of the inflammatory biomarker C-reactive protein (CRP) in the gingival fluid than controls without periodontitis, suggesting a protective effect of physical activity on this marker.

Regular exercise protects against diseases associated with chronic low-grade systemic inflammation. This long-term effect of exercise can be attributed to the anti-inflammatory response induced by an acute attack of exercise, which is partially mediated by IL-6 derived from the muscle. Physiological concentrations of IL-6 stimulate the onset, in the circulation, of anti-inflammatory cytokines of IL-1 ra (interleukin-1 receptor antagonist) and IL-10 and inhibit the production of TNF-a. Besides this, IL-6 stimulates lipolysis as well as oxidation of fats. The anti-inflammatory effects of exercise may provide protection against TNF-a-induced insulin resistance ${ }^{15}$.

The study by Núñez et al. (2014)7, evaluating the biological markers of oxidative stress in the saliva and their relationship with periodontal disease in physically inactive elderly patients with periodontal disease, found a significant increase in total antioxidant capacity and antioxidant enzyme activity in the group that performed Tai Chi, thus suggesting an antioxidant effect of Tai Chi and improvement of periodontal disease.
According to these authors, oxidative stress has been associated with the pathophysiology of periodontal disease due to reactive oxygen species that can selectively destroy proteoglycans associated with periodontal soft tissues and alveolar bone, as well as type one collagen aminoacid chains, significantly altering the function of fibroblasts, activating NF-kB (nuclear factor kappa-beta) and triggering the signaling of the cascade that activates osteoclasts leading to inflammation.

Research on potentially protective modalities to prevent or stop the rate of progression of periodontitis is obviously necessary. Despite the promising impact of maintaining regular physical activity in reducing the risk of various chronic conditions, ${ }^{16}$ the effects of physical exercise on inflammatory parameters and alveolar bone loss in individuals with PD have been poorly investigated. ${ }^{8}$

\section{CONCLUSION}

Considering certain experimental conditions, we can conclude that there was a protective effect of physical exercise at the height of the mandibular alveolar bone crest of rats doing physical exercise with periodontal disease, having no effect on the amount of osteoblast and osteocyte cells, thereby not influencing bone density. It is important to note the pioneering nature of this study in establishing these relationships, and further research is needed to better understand them.

All authors declare no potential conflict of interest related to this article

AUTHORS' CONTRIBUTIONS: Each author has contributed individually and significantly to the development of this manuscript. BMB (0000-0003-0272-6342)*: writing, revision and performance of surgeries; PHCR (0000-0003-3381-2382)*: surgeries and writing; LUAB (0000-0003-4732-3774)*: surgeries and analysis of the slides; DSL (0000-0001-6889-6200)* analysis of the slides and revision; GRFB (0000-0002-8647-413X)*: revision and the whole intellectual concept of the manuscript; CAN (0000-0002-8647-413X)*: writing, statistical analysis and intellectual concept of the manuscript and preparation of the entire research project; PON (0000-0003-3791-0334)*: writing, statistical analysis, intellectual concept of the manuscript and preparation of the entire research project. ${ }^{*} \mathrm{ORCID}$ (Open Researcher and Contributor ID).

\section{REFERENCES}

1. Burghardt PR, Fulk LJ, Hand GA, Wilson MA. The effects of chronic treadmill and wheel running on behavior in rats. Brain Res. 2004;10(19):84-96.

2. Nieman DC. Influence of carbohydrate on the immune response to intensive pro- longed exercise. Exerc Immunol Rev. 1998;4:64-76.

3. Fehr $\mathrm{HG}$, Lotzerich $\mathrm{H}$, Michina $\mathrm{H}$. Human macrophage function and physical exercise: phagocytic and histochemical studies. Eur J Appl Physiol Occup Physiol. 1989;58(6):613-7.

4. Pradhan AD, Manson JE, Rifai N, Buring JE, Ridker PM. C-reactive protein, interleukin 6, and risk of developing type 2 diabetes mellitus. J Am Med Assoc. 2001;286(6):327-34.

5. Aranciabia R, Oyarzu'n A, Silva D, Tobar N, Martínez J, Smith P. Tumor necrosis fator- a inhibits transforming growth fator- $\beta$-stimulated myofibroblastic differentiation and extracellular matriz production in human gingival fibroblasts. J Periodontol. 2013;84:683-93.

6. Sanders AE, Slade GD, Fitzsimmons TR, Bartold PM. Physical activity, inflammatory biomarkers in gingival crevicular fluid and periodontitis. J Clin Periodontol. 2009;36(5):388-95.

7. Núñez VMM, Monjaraz BH, Osorio ES, Rule JMB, Ramos MR. Tai Chi Exercise Increases SOD Activity and Total Antioxidant Status in Saliva and Is Linked to an Improvement of Periodontal Disease in the Elderly. Oxid Med Cell Longev.2014;2014:603853.

8. Andrade EF, Orlando DR, Gomes JAS, Foureaux RC, Costa RC, Varaschin MS, et al. Exercise attenuates alveolar bone loss and anxiety-like behaviour in rats with periodontitis. J Clin Periodontol. 2017;44(11):1153-63.
9. Brandão LUA, Bortolini BM, de Carli PH, Alegre-Maller ACP, Brandão CG, Ribeiro LFC, et al. Changes in the soleus muscular tissue of rats with experimental periodontitis under physical exercise influences. Arch Med Deporte. 2017;34(5):267-73.

10. Nassar PO, Nassar CA, Guimarães MR, Aquino SG, Andia DC, Muscara MN, et al. Simvastatin therapy in cyclosporine A-induced alveolar bone loss in rats. J Periodontal Res. 2009;44(4):479-88.

11. Artifon EL, Silva LI, Ribeiro LFC, Brancalhão RMC, Bertolini GRF. Treinamento aeróbico prévio à compressão nervosa: análise da morfometria muscular de ratos. Rev Bras Med Esporte. 2013;9(1):66-9.

12. Nassar CA, Nassar PO, Inagaki NS, Girelli Júnior C. Efeito de antiinflamatório no desenvolvimento da doença periodontal induzida. Avaliação radiográfica em ratos. Rev odontol UNESP. 2003;32(2):125-30

13. Junqueira LC, Carneiro J. Histologia básica. Rio de Janeiro: Guanabara Koogan; 1999

14. Beavers KM, Brinkley TE, Nickas BJ. Effect of exercise training on chronic inflammation. Clin Chim Acta. 2010;411(11-12):785-93

15. Petersen AM, Pedersen BK. The anti-inflammatory effect of exercise. J Appl Physiol Bethesda. 2005;98(4):1154-62

16. Albandar JM. Global risk factors and risk indicators for periodontal diseases. Periodontology 2000 2002;29(1):177-206 